University of Nebraska - Lincoln

DigitalCommons@University of Nebraska - Lincoln

\title{
Evaluation of $\boldsymbol{\beta}$-Glucosidase Activity as a Soil Quality Indicator for the Soil Management Assessment Framework
}

\author{
D. E. Stott \\ USDA-ARS, diane.stott@ars.usda.gov
}

S. S. Andrews

USDA-NRCS

M. A. Liebig

USDA-ARS

\author{
Brian J. Wienhold \\ University of Nebraska-Lincoln, Brian.Wienhold@ars.usda.gov \\ D. L. Karlen \\ USDA-ARS, doug.karlen@ars.usda.gov
}

Follow this and additional works at: https://digitalcommons.unl.edu/usdaarsfacpub

Stott, D. E.; Andrews, S. S.; Liebig, M. A.; Wienhold, Brian J.; and Karlen, D. L., "Evaluation of $\beta$-Glucosidase Activity as a Soil Quality Indicator for the Soil Management Assessment Framework" (2009). Publications from USDA-ARS / UNL Faculty. 1222.

https://digitalcommons.unl.edu/usdaarsfacpub/1222

This Article is brought to you for free and open access by the U.S. Department of Agriculture: Agricultural Research Service, Lincoln, Nebraska at DigitalCommons@University of Nebraska - Lincoln. It has been accepted for inclusion in Publications from USDA-ARS / UNL Faculty by an authorized administrator of DigitalCommons@University of Nebraska - Lincoln. 


\section{Evaluation of $\beta$-Glucosidase Activity as a Soil Quality Indicator for the Soil Management Assessment Framework}

D. E. Stott*

USDA-ARS

National Soil Erosion Research Lab. West Lafayette, IN 47907

\section{S. S. Andrews}

USDA-NRCS

National Soil Quality Technology

Greensboro, NC 27401-4901

\section{A. Liebig}

USDA-ARS

Northern Great Plains Research Lab. Mandan, ND 58554

\section{B. J. Wienhold}

USDA-ARS

Agroecosystem Management

Research Unit

Lincoln, NE 68583

\section{L. Karlen}

USDA-ARS

National Laboratory for Agriculture and the Environment

Ames, IA 50011
The Soil Management Assessment Framework (SMAF) was developed to assess conservation effects on soil, and uses multiple soil quality indicator measurements to compare soil functioning. Our objective was to develop a SMAFcompatible scoring equation for soil $\beta$-glucosidase (BG) activity using published data sets representing different soils and management. The resulting equation was an S-shaped curve: $y=a /[1+b \exp (-c x)]$, where $x$ is the measured BG activity ( $\mathrm{mg} p$-nitrophenol [PNP] released $\mathrm{kg}^{-1}$ soil $\mathrm{h}^{-1}$ ), $a$ and $b$ are constants, and $c$ is a factor modified by soil classification, texture, and climate. Data from a study conducted near Mandan, ND were used to test the model for sensitivity to crop management systems. Soil organic C (SOC) content at the site measured 247 to $687 \mathrm{~g} \mathrm{~kg}^{-1}$, while $B G$ activity ranged from 33 to $675 \mathrm{mg} \mathrm{kg}^{-1} \mathrm{~h}^{-1}$. Using SMAF, SOC indicator scores ranged from 0.25 to 0.73 , while $B G$ activity scores varied from 0.17 to 0.93 . As the work progressed, it became apparent that when $\mathrm{BG}$ activity values were normalized to the $\mathrm{SOC}$ content, the resulting ratio could indicate $\mathrm{C}$ sequestration trends, with ratios of 10 to $17 \mathrm{~g} \mathrm{PNP} \mathrm{kg}^{-1} \mathrm{SOC} \mathrm{h}^{-1}$ reflective of systems in equilibrium. Ratios $>17$ were mostly from recently altered management systems with SOC contents trending upward, while ratios $<10$ were generally from soils that were expected to continue to lose soil $\mathrm{C}$. The application of a sensitive $\mathrm{C}$ cycling enzyme activity such as BG should improve the SMAF soil quality assessments for soil functions where soil metabolic activity or $\mathrm{C}$-cycle enzyme activity play a role.

Abbreviations: BG, $\beta$-glucosidase; CEAP, Conservation Effects Assessment Project; CRP, Conservation Reserve Program; MBC, microbial biomass carbon; PNP, $p$-nitrophenol; SMAF, Soil Management Assessment Framework; SOC, soil organic carbon; SOM, soil organic matter.

$\mathrm{T}$ oday our soils are expected to produce food, fiber, feed, and fuel while maintaining and protecting our air, water, and soil resources. Soil and water quality are inherently linked (National Research Council, 1993). Assessing soil quality on a watershed scale may be the link needed to demonstrate how agricultural management practices impact water quality in streams (National Research Council, 1993; Karlen et al., 2008). While the concept of a performance-based rating for soil is not new, it has most often been related to crop productivity (Cambardella et al., 2004). The soil quality concept has been broadened to include the soil's impact on the environment. It has been suggested that enhancing soil quality is critical for maintaining and improving water quality (Kennedy and Papendick, 1995). There continues to be a number of soil quality issues in the United States, including continued high rates of erosion, reductions in soil fertility and production, and exposure to chemical and heavy metal pollution (Karlen and Stott, 1994; Karlen et al., 2001; Doran, 2002; Andrews et al., 2004).

In 2003, the Conservation Effects Assessment Project (CEAP) was initiated to provide a scientific basis for a national assessment of conservation practices by the NRCS (Richardson et al., 2008). Initially, the primary thrust of CEAP was to assess the impact on water quality of implementing conservation practices within agricultural watersheds. In 2006, a study was initiated to assess the effects of these same conservation practices on soil quality within the USDA-ARS's 14 CEAP experimental watersheds.

For cropland, soil quality for a specific site can be affected by the interaction of many factors including tillage, crop rotation, and other management factors, as

Soil Sci. Soc. Am. J. 74:107-119

Published online 1 Dec. 2009

doi:10.2136/sssaj2009.0029

Received 22 Jan. 2009.

*Corresponding author (diane.stott@ars.usda.gov).

(C) Soil Science Society of America, 677 S. Segoe Rd., Madison WI 53711 USA

All rights reserved. No part of this periodical may be reproduced or transmitted in any form or by

any means, electronic or mechanical, including photocopying, recording, or any information storage and retrieval system, without permission in writing from the publisher. Permission for printing and for reprinting the material contained herein has been obtained by the publisher. 
well as climate and soil type. Assessment tools are needed to evaluate the impact of management systems on critical soil functions related to soil quality, including nutrient cycling and water partitioning. Such tools need to be flexible with regard to the selection of soil functions to be assessed and indicators of the selected critical functions to be measured to ensure that the assessments are suitable for the management goals of interest. They also need to be sensitive to management changes, preferably within a year or two after implementation. For CEAP, the tool selected to help assess the impacts of management on soil was the SMAF (Andrews et al., 2004). A peer-reviewed NRCS report (Potter et al., 2006) described the use of the interpretation step of the SMAF for the national modeling portion of the CEAP project.

The SMAF provides site-specific interpretations for soil quality indicator results, and a beta version is now available (soilquality.org/tools/smaf_intro.html; verified 19 Sept. 2009) or from us. The SMAF uses measured soil indicator data to assess management effects on soil functions using a three-step process that includes indicator selection, indicator interpretation, and integration into an index. Indicators used in the SMAF include soil physical, chemical, and biological characteristics that are management sensitive and therefore dynamic. Currently, the SMAF includes 10 indicators with scoring curves consisting of interpretation algorithms (some including logic functions). They are: aggregate stability, plant-available water holding capacity, bulk density, electrical conductivity, $\mathrm{pH}, \mathrm{Na}$ adsorption ratio, soil $\mathrm{P}, \mathrm{SOC}$, microbial biomass $\mathrm{C}(\mathrm{MBC})$, and potentially mineralizable $\mathrm{N}(\mathrm{PMN})$. Interpretation algorithms that have been recently developed are water-filled pore space and Mehlichextractable K (Wienhold et al., 2009). Nevertheless, the SMAF uses soil taxonomy as a foundation for assessment, allowing for the modification of many of the scoring indicator values based on soil suborder characteristics, and providing a contextual basis for indicator interpretation. Soil quality and its assessment is soil and site specific and depends on a variety of factors, including inherent soil characteristics, environmental influences such as climate, and human values such as intended land use, management goals, and environmental protection, all of which are considered (and can be manipulated by the user) in the SMAF tool.

Other soil quality assessment tools exist. The Soil Conditioning Index (SCI), which has been adopted by the NRCS, estimates the effects of crop management on SOC levels (NRCS, 2002). The SCI was designed to determine if SOC levels would increase, decrease, or remain stable under a given management system. When the SCI was compared with the SMAF SOC indicator (a more direct comparison than using the full suite of SMAF indictors), the SMAF SOC was more successful in separating the tested cropping systems (Zobeck et al., 2008). The AgroEcosystem Performance Assessment Tool (AEPAT) is a research-oriented index methodology that ranks agroecosystem performance among management practices for chosen functions and indicators (Liebig et al., 2004). There is general agreement between the AEPAT and the SMAF (Wienhold et al., 2006); however, the input requirements and intended uses of the two tools are different, making a direct comparison difficult. There is also a farmer-oriented assessment tool: the Cornell Soil Health Test (Idowu et al., 2008). This assessment is narrowly tailored to assess only the crop production function of the soil.

Karlen et al. (2008) compared the SMAF with the SCI, the soil tillage intensity rating (STIR), and the N-leaching index that have been incorporated in the Revised Universal Soil Loss Equation, Version 2 (RUSLE2). The RUSLE2 estimates soil loss due to rill and interrill erosion caused by rainfall on cropland (USDA-ARS, 2005; Lightle, 2007). The STIR was developed to replace the soil disturbance rating used in the original SCI, and can function as a stand-alone rating to evaluate tillage and planting effects on factors other than ground cover and surface residue distribution. The N-leaching index is computed based on the soil hydrologic group and annual and winter rainfall (Pierce et al., 1991) and can be used to compare the potential for $\mathrm{N}$ leaching among various management systems. The SMAF soil quality index was significantly negatively correlated with soil loss $(-0.46$, $P<0.0001)$ as calculated by RUSLE2 and the N-leaching in$\operatorname{dex}(-0.51, P<0.0001)$, significantly positively correlated with the SCI $(0.29, P<0.0001)$, and showed no correlation with the STIR rating (0.08). The SMAF appeared to provide more information about the effects of management practices within the watershed examined (Karlen et al., 2008).

To increase the sensitivity of the SMAF to management impacts, the development of additional indicator scoring curves has been encouraged. Scoring curve development is a multistep process starting with the identification of an indicator, determining the type of relationship between the indicator and a specific soil function, identifying an appropriate mathematical equation(s) describing that relationship, and validating the scoring curve (Andrews et al., 2004; Wienhold et al., 2009). There are basically three types of relationships between scoring curves and soil function: (i) more is better (upper asymptotic sigmoid curve), (ii) less is better (lower asymptotic sigmoid curve), and (iii) having a midpoint optimum (Gaussian function) (Karlen and Stott, 1994; Andrews et al., 2004).

Currently the SMAF includes two microbial or biochemical indicators, PMN and MBC, both being represented by more-isbetter curves (Andrews et al., 2004). The inclusion of PMN is based on its relation to nutrient availability and a theorized relationship between microbial activity and plant productivity (Hendrix et al., 1990; Sparling, 1997), while MCB is included based on its role as a readily available pool of $\mathrm{C}$ and $\mathrm{N}$ and an association with improved soil structural functioning (Elliott and Coleman, 1988; Hendrix et al., 1990). Neither of these parameters address microbial activity or the potential metabolic activity of the soil.

Soil enzymes mediate and catalyze a number of soil biochemical and nutrient-cycling processes involved in soil functions and are considered to be the most likely candidates for determining early responses to changes in soil management (Dick et al., 1996). Enzyme activities will increase as a response to increases in soil microbial populations and the resulting increase in enzyme synthesis, as microorganisms are the major source of enzymes in soil 
(Tabatabai, 1994). Despite the short life-cycle of microorganisms, however, most enzymes continue to contribute to the metabolic capacity of the soil. Enzymes can be excreted by living cells or released by disintegrating cells to become free enzymes. In soil, free enzymes become adsorbed on organic and mineral constituents or complexed with humic substances or both. When soil is sampled to compare management impacts on soil functions, it provides a snapshot of the soil ecosystem as it exists at the time of sampling. Thus, while changes in enzymatic activities may be correlated with simultaneous changes in the soil microbial population, the shifts in activities are just as apt to reflect long-term fluctuations in microbial biomass and not necessarily the current population level.

Of the enzymes for which assay procedures exist for the soil environment, $\mathrm{BG}$ is one of the immobilized enzymes most often reported in the literature and has been suggested as an indicator of management effects (Bandick and Dick, 1999). The BG enzyme (EC 3.2.1.21; obsolete name: cellobiase) plays a major role in the degradation of soil organic matter and plant residues. It catalyzes the hydrolysis of $\beta$-D-glucopyranosides in the final, rate-limiting step in the degradation of cellulose, the most abundant polysaccharide in the earth, providing simple sugars for the soil microbial population. While no single enzyme activity can provide a full picture of soil metabolic functioning, BG has been shown to be sensitive to changes in soil and residue management as well as an early indicator of changes in SOC before these changes are reflected in total or organic C analyses (Miller and Dick, 1995; Deng and Tabatabai, 1996; Aon and Colaneri, 2001; Turner et al., 2002; Acosta-Martínez et al., 2003a; de la Horra et al., 2003; Roldán et al., 2005; Green et al., 2007). An increasing BG activity, which usually increases with increasing soil microbial biomass, would reflect on a soil's ability to break down plant residues and improve the availability of nutrients for subsequent crops. Within the structure of the SMAF, relative BG activity would relate to the following soil functions due to its importance in $\mathrm{C}$ cycling and providing simple sugars to support a diverse microbial population: nutrient cycling (for plant growth), biodiversity and habitat (within the soil and the plants and animals sustained by the soil), filtering and buffering (excess nutrients and toxic chemicals from the water), and physical stability and support (soil structure).

There has been some comparison of cropland activities to those found in native ecosystems and long-term (>10-yr) no-till, Conservation Reserve Program (CRP) land, and pastures. The activities of BG were generally two to five times greater in these systems than the typical conventional cropping systems, and one and a half to three times higher than conservation systems, with greater disparity occurring in the temperate climates (Bandick and Dick, 1999; Acosta-Martínez et al., 2003a, 2007b; de la Horra et al., 2003). Elevated levels of BG activity can be found within 1 to $3 \mathrm{yr}$ of changing management from conventional to conservation or notill practices (Roldán et al., 2005). Within the same soil type, BG activity is higher in more intensive cropping systems (Bandick and Dick, 1999; Acosta-Martínez et al., 2003a, 2007b), with systems that include a fallow period having among the lowest activity rates.
Large additions of organic material can initially result in two- to fourfold increases in BG activity, but subsequent additions do not sustain the high levels of activity (Martens et al., 1992). Soil structural improvement, as measured by decreased bulk density and increased infiltration rates, have resulted in enhanced levels of BG activity with time when compared with preamendment activities. In general, improved soil aggregation resulted in higher BG activity levels (Roldán et al., 2005).

For the CEAP soil quality assessment, BG activity will be measured at the 14 experimental watershed sites. To increase the usefulness of BG activity as a soil quality indicator for CEAP, a SMAF indicator curve is needed for this important biochemical measurement. The assessment of soil enzyme activity, including BG activity, is simple and has relatively low labor costs when compared with other soil biochemical analyses (Ndiaye et al., 2000; AcostaMartínez et al., 2007a). Our objectives were to develop a set of algorithms to describe BG activity, as an indicator of soil metabolic activity, for use as a SMAF indicator and to provide an initial validation using published literature. An additional objective was assess BG activities in the same soil under different no-till cropping systems just before and $1 \mathrm{yr}$ after implementation. The field experiment hypotheses were that the SMAF BG activity indicator would be sensitive to changes due to the different cropping systems.

\section{MATERIALS AND METHODS Soil Management Assessment Framework Curve Development for $\beta$-Glucosidase Activity}

The basic procedure for SMAF curve development has been published previously (Andrews et al., 2004; Wienhold et al., 2009). A SMAF scoring curve consists of an algorithm or a logic statement (if, then, else) with multiple algorithms. The algorithms should be quantitative relationships between measured values of the indicator and a normalized, unitless score that represents the indicator's performance as part of a soil function(s). While it is assumed that the general shape of the relationship between a soil indicator and a soil function holds across ecosystems, the range for an indicator will vary among ecosystems. The variation from system to system results from differences in site-specific factors such as climate or inherent soil properties. Curve-fitting software is used to describe the general shape and help identify and calibrate site-specific coefficients to provide the appropriate contextual variation in the expected range.

$\beta$-Glucosidase activity has not been studied in relation to any of the soil functions described in the SMAF (Andrews et al., 2004), so we chose to relate BG activity to SOC because SOC content is a component of many of the soil functions outlined in the SMAF. The initial relationship between BG activity and soil C was determined by graphing the data and determining the general shape of the relationship (i.e., more is better, less is better, or local optimum). Once the relationship shape was defined, curve-fitting software (CurveExpert, version 1.3 shareware, available at curveexpert.webhop.net/; verified 19 Sept. 2009) was used to develop an algorithm that describes the relationship. CurveExpert compares the fit of the data to a library of available models, selects the model having the lowest root mean square error, and provides coefficient estimates for the model exhibiting the best fit. 
Table 1. The soil organic matter factor classes used to determine the soil organic $C$ indicator index value, as used in the Soil Management Assessment Framework (Andrews et al., 2004), presented in the first Conservation Effects Assessment Project report (Potter et al., 2006), and proposed for use in calculating the $\beta$-glucosidase indicator index value. Class 1 represents the suborders that tend to have the highest potential for sequestering SOC, while Class 4 has the lowest.

\begin{tabular}{|c|c|c|c|}
\hline Class 1 (High) & Class 2 & Class 3 & Class 4 (Low) \\
\hline Andisols & Andisols & Alfisols & Andisols \\
\hline Aquands & Udands & Aqualfs $\neq$ & Torrands \\
\hline Gelisols & Ustands & Boralfs & Xerands \\
\hline Histels & Inceptisols & Cryalfs & Aridisols \\
\hline Turbels & Aquepts & Udalfst‡ & Argids \\
\hline Histosols & Mollisols & Ustalfst‡ & Calcids \\
\hline Fibrists & Albolls & Xeralfst & Cambids \\
\hline Folists & Aquollst‡ & Andisols & Cryids \\
\hline Hemists & Borolls & Cryands & Durids \\
\hline Saprists & Cryolls & Vitrands & Gypsids \\
\hline Oxisols & Rendolls & Entisols & Orthids \\
\hline Aquoxs & Udollst‡ & Aquents & Salids \\
\hline Spodosols & Ustollst‡ & Gelisols & Entisols \\
\hline \multirow[t]{28}{*}{ Aquods } & Xerollst‡ & Orthels & Arents \\
\hline & Oxisols & Inceptisols & Fluvents \\
\hline & Udox & Andepts & Orthents $\neq$ \\
\hline & Spodosols & Anthrepts & Psamments \\
\hline & Humods & Spodosols & Xerents \\
\hline & Ultisols & Cryods & Inceptisols \\
\hline & Aquults & Vertisols & Cryepts \\
\hline & Humults $\neq$ & Cryerts & Ochrepts \\
\hline & Vertisols & & Tropepts \\
\hline & Aquertst & & Udepts \\
\hline & Xererts & & Umbrepts \\
\hline & & & Ustepts \\
\hline & & & Xerepts \\
\hline & & & Oxisols \\
\hline & & & Orthox \\
\hline & & & Perox \\
\hline & & & Torrox \\
\hline & & & Ustoxt \\
\hline & & & Spodosols \\
\hline & & & Orthods \\
\hline & & & Ultisols \\
\hline & & & Udults \\
\hline & & & Ustults \\
\hline & & & Xerults \\
\hline & & & Vertisols \\
\hline & & & Torrerts \\
\hline & & & Usterts \\
\hline & & & Uderts \\
\hline
\end{tabular}

† Soil suborders used in curve development.

₹ Soil suborders used in curve validation.

Once the basic algorithm has been developed, the impact of inherent soil differences must be considered. The inherent differences include characteristics such as soil classification, texture, and climate. These inherent characteristics might cause a shift in the expected range of the BG activity indicator or in the relationship between BG and the selected soil function (SOC). From the preponderance of the literature, we determined that the factors most likely to affect the expected range of BG were inherent soil organic matter (determined using U.S. soil taxonomic suborders), soil texture, and climate (Tables 1-3). The determination of how these factors affect the expected range occurred during curve calibration.

\section{Data Set Selection}

The scientific literature was searched for a variety of data sets containing measurements of BG activity. Several criteria were used to determine if a data set should be used for the development or validation process. These included: (i) BG activity was reported as the release of PNP using methods based on Eivazi and Tabatabai (1988); (ii) the soil series or suborder was given; (iii) soil texture was determined; (iv) SOC content was measured or soil organic matter (SOM) content was reported; (v) the experimental location was specified or climatic information was included; and (vi) there were multiple treatments such as crop rotation, tillage practices, or site comparisons resulting in a range of BG activities. Data sets meeting these criteria were divided for use in development (D) or validation $(\mathrm{V})$ to maximize the diversity within each group and to maximize overlap, particularly in the soil and climate conditions, between the two groups. The sets used in the developmental stage were chosen so that each grouping of soil orders, soil textures, and climates were represented. The remainder of the data sets were used for validation.

\section{Field Experiment}

The Mandan validation experiment was a subset of a larger project described by Tanaka et al. (2007). The crop $\times$ crop-residue matrix experiment was located at the Area IV Soil Conservation District, USDA-ARS Northern Great Plains Research Laboratory's research farm approximately $7 \mathrm{~km}$ southwest of Mandan, ND (46. $\left.46^{\prime} 22^{\prime \prime} \mathrm{N}, 100^{\circ} 57^{\prime} 9^{\prime \prime} \mathrm{W}\right)$. The experiment was comprised of two sites (north and south), with soils classified as Temvik-Wilton silt loams (fine-silty, mixed, superactive, frigid Typic and Pachic Haplustolls). Before initiating the experiment, the sites were seeded to an oilseed sunflower (Helianthus annuus L.)-spring wheat (Triticum aestivum L.)-spring wheat crop sequence beginning in 1999 for the north site and 2000 for the south site. The inclusion of two sites for the experiment provided four site years of data. During the first year of the crop $x$ crop-residue matrix experiment (2002 and 2003 for the north and south sites, respectively), 10 crops were no-till seeded into spring wheat stubble: buckwheat (Fagopyrum esculentum Moench), canola (Brassica napus L.), chickpea (Cicer arietinum L.), corn (Zea mays L.), dry pea (Pisum sativum L.), grain sorghum [Sorghum bicolor (L.) Moench], lentil (Lens culinaris Medik.), oilseed sunflower, proso millet (Panicum miliaceum L.), and hard red spring wheat. In the second year, the same crops were no-till seeded perpendicular over the residue of the previous year's crop, resulting in a $10 \times 10$ matrix with 100 treatment combinations. Treatments were replicated four times each year following a strip-block design. Cultural practices used during the experiment were similar to that of local no-till producers. Planting and harvesting operations were conducted based on locally optimal time periods for each crop. Additional details regarding management of the applied treatments can be found in Tanaka et al. (2007).

Soil samples were collected in the spring before planting and taken only from plots that were to be planted to corn in the second year. The first sampling occurred the spring after the preliminary 3-yr rotation of sunflower-spring wheat-spring wheat, while a second sampling 
Table 2. The texture class used to determine the soil organic C (SOC) indicator index value, as presented in the Soil Management Assessment Framework (Andrews et al., 2004; Potter et al., 2006), and proposed for use in calculating the $\beta$-glucosidase indicator index value. Class 1 represents the texture groups that have the lowest intrinsic potential for sequestering SOC, while Class 5 has the highest. Texture groups are based on the work of Quisenberry et al. (1993).

\begin{tabular}{cc} 
Class & Texture group \\
\hline 1 & sand \\
loamy sand \\
sandy loam (with $<8 \%$ clay) \\
sandy loam (with clay $>8 \%$ ) \\
sandy clay loam \\
loam \\
silt loam \\
silt \\
4 & sandy clay \\
& clay loam \\
& silty clay loam \\
& silty clay \\
& clay $(<60 \%)$ \\
& clay $(>60 \%)$ \\
\hline
\end{tabular}

occurred the spring after the initial 10 crops were harvested. Samples were collected from three replicates at each site where inherent soil conditions were most uniform based on inspection of a soil survey map (Replicates 1,2, and 4 for the north site and Replicates 5, 7, and 8 for the south site). In each plot, 10 soil cores were collected from the 0 - to $5-\mathrm{cm}$ depth, bulked, stored in a plastic bag, and kept in cold storage at $4^{\circ} \mathrm{C}$ until processing. Samples were air dried and ground to pass a $2.0-\mathrm{mm}$ sieve. Identifiable root material was removed during sieving.

The total SOC content was determined by dry combustion using a LECO CHN 2000 Analyzer (LECO Corp., St. Joseph, MI). There were no detectable carbonates, so the total $\mathrm{C}$ content was considered equal to the organic $\mathrm{C}$ content. The BG activity was determined using the method of Eivazi and Tabatabai (1988) and expressed as milligrams PNP released per kilogram of soil per hour of incubation.

\section{RESULTS AND DISCUSSION Assumptions for Algorithm Development}

The activity of BG has not been studied in relation to the soil functions designated in the SMAF. Since BG activity plays a role in plant residue decomposition and SOC cycling, however, we chose SOC as a comparative factor since it is a component of several of the SMAF soil functions; nonetheless, this is an imperfect comparison. The BG activity is often significantly correlated to SOC within a given study, and accounts for 53 to $100 \%$ of the variation $\left(r^{2}\right)$ in the observed BG activity (Bergstrom et al., 1998; Mullen et al., 1998; Bandick and Dick, 1999; Dumontet et al., 2001; Taylor et al., 2002; Acosta-Martínez et al., 2003b, 2004, 2007b; de la Horra et al., 2003; Roldán et al., 2005; Leon et al., 2006). There are many exceptions, however, with those studies showing no significant correlation ( $r^{2}$ from 0.13 to 0.42 ) between SOC and BG activity within a soil type (Eivazi and Tabatabai, 1988; Ajwa et al., 1999; Bandick and Dick, 1999; Taylor et al., 2002; Acosta-Martínez et al., 2003a; Dodor and Tabatabai, 2005). Another exception is for Oxisols, either with native Cerrado vegetation or planted to corn (Green et al., 2007;
Table 3. The climate classes used to determine the soil organic $C$ indicator index value, as presented in the Soil Management Assessment Framework (Andrews et al., 2004; Potter et al., 2006), and proposed for use in calculating the $\beta$-glucosidase indicator index value.

\begin{tabular}{cccc} 
Class & $\begin{array}{c}\text { Climate } \\
\text { designation }\end{array}$ & $\begin{array}{c}\text { Growing degree } \\
\text { days }\end{array}$ & Precipitation \\
\hline & & & $\mathrm{mm}$ \\
1 & high/high & $\geq 170$ & $\geq 550$ \\
2 & high/low & $\geq 170$ & $<550$ \\
3 & low/high & $<170$ & $\geq 550$ \\
4 & low/low & $<170$ & $<550$ \\
\hline
\end{tabular}

Green and Stott, unpublished data, 2008), where BG activities were significantly correlated with $\mathrm{P}$ content, the limiting nutrient in that region, but were poorly correlated with SOC content. Also, large additions of various organic amendments to soil have been shown to result in temporary two- to four-fold increases in BG activity, with only a minor shift in SOC content (Martens et al., 1992). Furthermore, those increases peaked and were not sustained, despite additional organic inputs.

In the SMAF, the MBC indicator is affected by season, while SOC is not. There appears to be little seasonal impact on BG activity (Ajwa et al., 1999; Bandick and Dick, 1999; Acosta-Martínez et al., 2004; Bastida et al., 2006), therefore seasonal affects were not considered to be important in developing these algorithms. Annual fluctuations in temperature and rainfall, which impact soil microbial biomass and plant growth, can impact BG levels within an ecosystem, however, and so should be considered when interpreting scores (Acosta-Martínez et al., 2004; Dodor and Tabatabai, 2005).

Since BG activity is generally related to SOC contents within a given study, especially in ecosystems where an equilibrium has been reached, e.g., native vegetation, we assumed that the same groupings of soils, textures, and climates used for the SOC indicator within the SMAF model (Andrews et al., 2004) could be applied to the BG indicator. Soil suborder (Table 1) groupings were based on the potential of an individual suborder to sequester C, and are referred to as SOM factor classes. Soil texture was grouped into five classes (Table 2) based on the work of Quisenberry et al. (1993). Climate designations were based on rainfall and temperature (Table 3). If climate data were missing from a data set within the United States, the Major Land Resource Area (NRCS, 2006) was used to assign a climate class.

\section{Relationship between Soil Organic Carbon and $\beta$-Glucosidase Activity}

When BG activity was compared collectively to SOC contents from all of the development and validation data set studies (Table 4), there was a poor correlation (Fig. 1). If it is assumed, however, that ecosystems with native vegetation, long-term pastures, and long-term CRP lands are relatively stable (no shift in SOC content with time, and plant and soil microbial biomass are at stable, sustainable levels), then it might be assumed that SOC contents and BG activity levels would be in equilibrium. When $B G$ activity was normalized relative to $S O C\left(B G_{n}=B G\right.$ activity/ SOC content), such ecosystems had $\mathrm{BG}_{\mathrm{n}}$ values ranging from 10 
Table 4. Summary of data sets used in the development and validation of the $\beta$-glucosidase indicator equation $c$-factor values (sitespecific coefficients in algorithms) and scoring curves for use in the Soil Management Assessment Framework.

\begin{tabular}{|c|c|c|c|c|c|c|c|}
\hline \multirow[b]{2}{*}{ Reference } & \multirow{2}{*}{$\begin{array}{c}\text { Data } \\
\text { set IDt }\end{array}$} & \multirow[b]{2}{*}{ Location } & \multirow[b]{2}{*}{ Soil identification } & \multirow[b]{2}{*}{ Crop and soil management } & \multicolumn{3}{|c|}{ Range of values $¥$} \\
\hline & & & & & SOC & BG & $B G_{n}$ \\
\hline & & & & & $\mathrm{g} \mathrm{kg}^{-1}$ & $\mathrm{mg} \mathrm{kg}^{-1} \mathrm{~h}^{-1}$ & $\mathrm{~kg} \mathrm{SOC}^{-1} \mathrm{~h}^{-1}$ \\
\hline $\begin{array}{l}\text { Acosta-Martínez et } \\
\text { al. (2003b) }\end{array}$ & D01 & Lubbock, TX & Paleustoll loam & $\begin{array}{l}\text { cotton, wheat, sorghum in various } \\
\text { rotations and tillage regimes }\end{array}$ & $9.0-12.2$ & $43-156$ & $4.8-12.8$ \\
\hline $\begin{array}{l}\text { Dodor and Tabatabai } \\
(2005) \text {, Moore et al. } \\
(2000)\end{array}$ & D02 & lowa & Hapludoll loam & $\begin{array}{l}\text { corn, soybean, oat, meadow; } \\
\text { conventional tillage }\end{array}$ & $17.3-25.5$ & $87-277$ & $4.1-13.6$ \\
\hline $\begin{array}{l}\text { Eivazi and Tabatabai } \\
\text { (1988) }\end{array}$ & D03 & lowa & $\begin{array}{l}\text { Endoaquert silty clay, Haploudoll } \\
\text { clay loam, Calciaquoll clay loam, } \\
\text { Endoaquert silty clay loam, } \\
\text { Endoaquoll silty clay loam }\end{array}$ & $\begin{array}{l}\text { corn-soybean rotation; } \\
\text { conventional tillage } \\
\text { (original method development) }\end{array}$ & $25.4-54.5$ & $72-295$ & $5.7-6.8$ \\
\hline $\begin{array}{l}\text { Dodor and Tabatabai } \\
\text { (2005), Moore et al. } \\
\text { (2000) }\end{array}$ & D04 & lowa & Hapludoll clay loam & $\begin{array}{c}\text { corn, soybean, oat, meadow; } \\
\text { various rotations; } \\
\text { two fertilizer rates }\end{array}$ & $22.7-44.3$ & $89-272$ & $3.2-8.7$ \\
\hline Green et al. (2007) & D05 & $\begin{array}{l}\text { Sete Lagoas, } \\
\text { MG, Brazil }\end{array}$ & Paleudalf fine sandy loam & $\begin{array}{c}\text { corn-common bean rotation with } \\
\text { varying tillage regimes; native } \\
\text { vegetation }\end{array}$ & $27.4-41.6$ & $55-100$ & $1.7-3.5$ \\
\hline Roldán et al. (2005) & D06 & Mexico & Aquert clay & $\begin{array}{l}\text { native vegetation, long-term } \\
\text { moldboard plow, recent } \\
\text { conservation tillage }\end{array}$ & $7.4-12.6$ & $38-205$ & $5.1-16.3$ \\
\hline $\begin{array}{l}\text { Acosta-Martínez et } \\
\text { al. }(2003 b)\end{array}$ & D07 & Lubbock, TX & $\begin{array}{l}\text { Paleustalf sandy loam, } \\
\text { Paleustalf sandy clay loam }\end{array}$ & $\begin{array}{c}\text { cotton, wheat, peanut, sorghum } \\
\text { in various rotations and tillage } \\
\text { regimes }\end{array}$ & $1.4-9.6$ & $11-131$ & $4.0-42.0$ \\
\hline Martens et al. (1992) & D08 & Riverside, CA & Durixeralf sandy clay loam & $\begin{array}{l}\text { fallow; heavy manure or plant } \\
\text { residue additions }\end{array}$ & $4.1-7.4$ & $162-345$ & $27.7-63.0$ \\
\hline $\begin{array}{l}\text { Acosta-Martínez et } \\
\text { al. (2004) }\end{array}$ & D09 & $\begin{array}{l}\text { Gaines Co., } \\
\text { TX }\end{array}$ & Paleustalf sand & $\begin{array}{l}\text { cotton and peanut in varying } 3-y r \\
\text { rotations; deep tilled; irrigation } \\
\text { implemented }\end{array}$ & $1.4-2.1$ & $12.5-42$ & $8.2-24.9$ \\
\hline $\begin{array}{l}\text { Green and Stott } \\
\text { (unpulished data, } \\
\text { 2008) }\end{array}$ & D10 & Brazil & $\begin{array}{l}\text { Ustox sandy clay, } \\
\text { Ustox clay }(<60 \% \text { clay })\end{array}$ & $\begin{array}{c}\text { native Cerrado vegetation, } \\
\text { several sites }\end{array}$ & $19.2-31.6$ & $24-70$ & $0.8-2.3$ \\
\hline $\begin{array}{l}\text { Bandick and Dick } \\
\text { (1999) }\end{array}$ & D11 & Aurora, OR & Argixeroll silt loam & $\begin{array}{l}\text { vegetables with legume or cereal } \\
\text { cover crops or fallow; fescue grass } \\
\text { seed production }\end{array}$ & $13.7-16.5$ & $53-81$ & $3.4-5.8$ \\
\hline $\begin{array}{l}\text { Bandick and Dick } \\
\text { (1999) }\end{array}$ & D12 & $\begin{array}{l}\text { Pendleton, } \\
\text { OR }\end{array}$ & Haploxeroll silt loam & $\begin{array}{l}\text { long-term winter wheat-summer } \\
\text { fallow; fertility treatments; native } \\
\text { pasture }\end{array}$ & 9.0-15.2 & $42-202$ & $4.3-13.3$ \\
\hline $\begin{array}{l}\text { Dumontet et al. } \\
\text { (2001) }\end{array}$ & V01 & Italy & Ustorthent clay loam & $\begin{array}{l}\text { vetch, oat, wheat and fallow; } \\
\text { conventional or reduced tillage }\end{array}$ & $9.7-12.4$ & $221-380$ & $21.0-30.6$ \\
\hline $\begin{array}{l}\text { Acosta-Martínez et } \\
\text { al. (2007b) }\end{array}$ & V02 & Akron, $\mathrm{CO}$ & Paleustoll loam & $\begin{array}{l}\text { low-, medium-, high-intensity } \\
\text { cropping, pasture }\end{array}$ & $5.5-10.1$ & $42-156$ & $7.1-15.5$ \\
\hline $\begin{array}{l}\text { de la Horra et al. } \\
(2003)\end{array}$ & V03 & $\begin{array}{l}\text { Cordoba, } \\
\text { Argentina }\end{array}$ & Argiudoll silty clay loam & $\begin{array}{c}\text { native pasture; conventional and } \\
\text { no-till corn }\end{array}$ & $10.1-27.0$ & $121-295$ & $10.9-14.8$ \\
\hline $\begin{array}{l}\text { Acosta-Martínez et } \\
\text { al. (2003a) }\end{array}$ & V04 & Texas & Paleustalf loamy sand & $\begin{array}{c}\text { continuous cotton, conventional } \\
\text { tillage; cotton-wheat, conservation } \\
\text { tillage; Conservation Reserve } \\
\text { Program (CRP) }\end{array}$ & $3.4-4.0$ & $22-49$ & $6.8-16.5$ \\
\hline $\begin{array}{l}\text { Acosta-Martínez et } \\
\text { al. (2003a) }\end{array}$ & V05 & Texas & Paleustalf sandy loam & $\begin{array}{l}\text { continuous cotton, conventional } \\
\text { tillage; cotton-wheat, conservation } \\
\text { tillage; CRP, native rangeland }\end{array}$ & $3.1-14.1$ & $23-124$ & $6.4-13.5$ \\
\hline $\begin{array}{l}\text { Acosta-Martínez et } \\
\text { al. }(2003 a)\end{array}$ & V06 & Texas & $\begin{array}{c}\text { Paleustoll sandy loam, Paleustoll } \\
\text { sandy clay loam }\end{array}$ & $\begin{array}{c}\text { continuous cotton, conventional } \\
\text { tillage; cotton-wheat, conservation } \\
\text { tillage; sunflower, CRP, native } \\
\text { rangeland }\end{array}$ & $3.2-18.7$ & $31-231$ & $8.2-21.5$ \\
\hline $\begin{array}{l}\text { Knight and Dick } \\
(2004)\end{array}$ & V07 & $\begin{array}{l}\text { eastern } \\
\text { Oregon }\end{array}$ & Xeroll silt loam & $\begin{array}{c}\text { managed (wheat) vs. unmanaged } \\
\text { (cemetery) }\end{array}$ & $9.4-13.9$ & 135-190 & $13.7-14.4$ \\
\hline $\begin{array}{l}\text { Knight and Dick } \\
(2004)\end{array}$ & V08 & $\begin{array}{l}\text { western } \\
\text { Oregon }\end{array}$ & Albaqualf silt loam & $\begin{array}{c}\text { managed (annual rye grass) vs. } \\
\text { unmanaged land (native grassland) }\end{array}$ & $21-23$ & $80-111$ & $3.8-4.8$ \\
\hline
\end{tabular}


Table 4. (cont.)

\begin{tabular}{|c|c|c|c|c|c|c|c|}
\hline \multirow{2}{*}{ Reference } & \multirow{2}{*}{$\begin{array}{c}\text { Data } \\
\text { set ID+ }\end{array}$} & \multirow{2}{*}{ Location } & \multirow{2}{*}{ Soil identification } & \multirow{2}{*}{ Crop and soil management } & \multicolumn{3}{|c|}{ Range of values $¥$} \\
\hline & & & & & SOC & BG & $B G_{n}$ \\
\hline & & & & & $\mathrm{g} \mathrm{kg}^{-1} \quad \mathrm{r}$ & \multicolumn{2}{|c|}{$\mathrm{mg} \mathrm{kg}^{-1} \mathrm{~h}^{-1} \mathrm{~g} \mathrm{~kg} \mathrm{SOC}^{-1} \mathrm{~h}^{-1}$} \\
\hline $\begin{array}{l}\text { Bergstrom et al. } \\
\text { (1998) }\end{array}$ & V10 & Ontario & Hapludalf with various textures & $\begin{array}{l}\text { corn-soybean-winter wheat; no- } \\
\text { till vs. conventional tillage }\end{array}$ & $19-23$ & 109-139 & $4.7-7.0$ \\
\hline $\begin{array}{l}\text { Bergstrom et al. } \\
\text { (1998) }\end{array}$ & $\mathrm{V} 12$ & Ontario & $\begin{array}{l}\text { Hapludalf sandy loam, Hapludalf } \\
\text { loam }\end{array}$ & $\begin{array}{l}\text { corn, soybean, wheat; no-till vs. } \\
\text { conventional tillage }\end{array}$ & $17-37$ & $92-209$ & $2.6-6.1$ \\
\hline Ajwa et al. (1999) & V13 & $\begin{array}{c}\text { Konza Prairie, } \\
\text { Kansas }\end{array}$ & Argiustoll silty clay loam & $\begin{array}{l}\text { native grass; burned vs. unburned; } \\
\text { fertilized vs. unfertilized }\end{array}$ & 30-35 & $21-41$ & $0.7-1.3$ \\
\hline Mullen et al. (1998) & V14 & $\begin{array}{l}\text { western } \\
\text { Tennessee }\end{array}$ & Hapludalf silt loam & $\begin{array}{c}\text { corn, no-till; fertilized vs. } \\
\text { unfertilized; no cover crop vs. } \\
\text { hairy vetch }\end{array}$ & 10.0-16.9 & $58-172$ & $5.7-11.7$ \\
\hline
\end{tabular}

† D, development data set; $\mathrm{V}$, validation data set.

₹ SOC, soil organic C content; $\mathrm{BG}, \beta$-glucosidase activity in mg $\mathrm{p}$-nitrophenol released $\mathrm{kg}^{-1}$ soil $\mathrm{h}^{-1}$ incubation; $\mathrm{BG}_{\mathrm{n}}$, ratio of $\mathrm{BG}$ activity to SOC content.

to $17 \mathrm{~g}$ PNP released $\mathrm{kg}^{-1}$ SOC $\mathrm{h}^{-1}$ incubation (Tables 4 and 5) and appeared to be independent of soil type. Within the development and validation data sets (Table 4), there were 53 data points from 11 of the data sets that fell within this stable $B G_{n}$ range, and they exhibited a significantly high correlation between SOC content and BG activity (Fig. 1) with an $r^{2}$ of 0.95 . When developing the family of curves for the BG indicator scores, it was assumed that for data points in the development sets that were in the stable $\mathrm{BG}_{\mathrm{n}}$ range, the $\mathrm{BG}$ indicator score would be about equal to the SOC indicator score as calculated by the SMAF (Andrews et al., 2004). Examples of these stable systems included native vegetation (Acosta-Martínez et al., 2003a; de la Horra et
(>17 g PNP released $\mathrm{kg}^{-1} \mathrm{SOC} \mathrm{h}^{-1}$ incubation) $\mathrm{BG}_{\mathrm{n}}$ ratio (Martens et al., 1992; Dumontet et al., 2001; Acosta-Martínez et al., 2003a,b, 2004). Twenty-one data points fell in the high range $\left(\mathrm{BG}_{\mathrm{n}}>17 \mathrm{~g}\right.$ PNP released $\mathrm{kg}^{-1} \mathrm{SOC} \mathrm{h}^{-1}$ incubation), with an $r^{2}$ of 0.87 .

\section{Curve Development}

For developing the family of curves, 12 data sets were culled from eight published and one unpublished study (Table 4). Those data sets provided a range of soil orders, soil textures, climates, and management practices (Table 4). Two studies that included multiple sites with differing soil orders or textures were divided al., 2003; Roldán et al., 2005), longterm pasture or legume crop (Bandick and Dick, 1999; de la Horra et al., 2003; Acosta-Martínez et al., 2004, 2007b; Knight and Dick, 2004), and long-term conservation tillage or notill management (Acosta-Martínez et al., 2003a,b). Systems that had ratios below this range $(<10 \mathrm{~g}$ PNP released $\mathrm{kg}^{-1} \mathrm{SOC} \mathrm{h}^{-1}$ incubation) were generally considered to have a continual loss of SOC. These points comprised $67 \%$ of the 226 data points used in this study, with an $r^{2}$ of 0.67 . The greater spread among the lowrange data points was probably due to multiple factors other than SOC content limiting the BG activity. Systems that had moved to no-till or other conservation practices had either started or were anticipated to start accumulating SOC, based on earlier studies, and had increasing soil microbial activity and a high

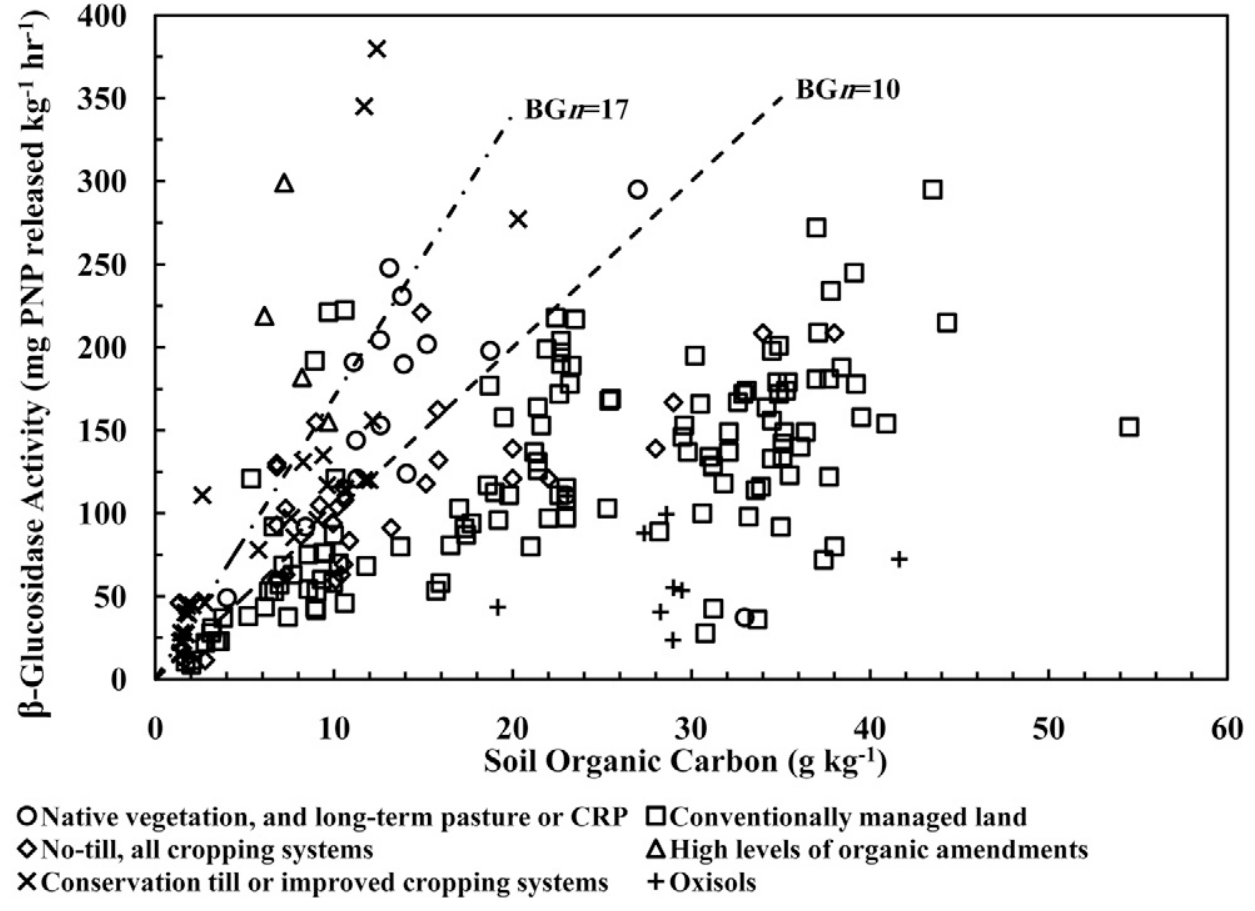

Fig. 1. Soil organic C (SOC) vs. $\beta$-glucosidase (BG) activity for the development and validation data sets used to determine site-specific coefficient ( $c$ factor) values for use in Eq. [1]. The data represent a broad range of soil and climatic conditions (Table 4). Lines represent normalized 8 pt-glucosidase activities $\left(B_{n}=B G\right.$ activity/SOC content of 10 and $17 \mathrm{~g}$ p-nitrophenol [PNP] released $\mathrm{kg}^{-1} \mathrm{SOC}^{-1}$ incubation). 
Table 5. Key endpoint samples from the data sets in Table 4 used in developing the Soil Management Assessment Framework indicator scoring curves for $\beta$-glucosidase activity.

\begin{tabular}{|c|c|c|c|c|c|c|c|c|}
\hline $\begin{array}{l}\text { Data set } \\
\text { IDt }\end{array}$ & $\begin{array}{l}\text { Points in } \\
\text { data set¥ }\end{array}$ & Class§ & Management $\mathscr{T}$ & $\begin{array}{l}\text { SOC } \\
\text { score } \#\end{array}$ & BG activity+† & $B G_{n} \neq \ddagger$ & $\begin{array}{c}\text { Target } \\
\text { range§§ }\end{array}$ & $\begin{array}{l}\text { Final BG } \\
\text { score } \llbracket \text { ฯ }\end{array}$ \\
\hline & & & & & $\mathrm{mg} \mathrm{kg}^{-1} \mathrm{~h}^{-1}$ & $\mathrm{~kg}^{-1} \mathrm{~h}^{-}$ & & \\
\hline \multirow[t]{3}{*}{ D01 } & & & continuous cotton, conventional tillage, irrigated & 0.11 & 43 & 4.8 & $0.03-0.05$ & 0.04 \\
\hline & 13 & $2-2-2$ & wheat-cotton, reduced tillage, irrigated & 0.19 & 156 & 12.8 & $0.15-0.25$ & 0.19 \\
\hline & & & cotton with rye cover crop, no-till, irrigated & 0.14 & 116 & 11.0 & $0.10-0.16$ & 0.11 \\
\hline \multirow{3}{*}{ D02 } & & & corn-soybean, conventional tillage, $0 \mathrm{~kg} \mathrm{~N}$ & 0.38 & 177 & 9.5 & $0.23-0.36$ & 0.21 \\
\hline & 26 & $2-2-3$ & corn-corn-oat-alfalfa,conventional tillage, $81.6 \mathrm{~kg} \mathrm{~N}$ & 0.46 & 277 & 13.6 & $0.39-0.62$ & 0.52 \\
\hline & & & corn-corn-oat-alfalfa, conventional tillage, 0 kg N & 0.57 & 204 & 9.0 & $0.32-0.51$ & 0.28 \\
\hline D03 & 5 & $2-4-3$ & $\begin{array}{c}\text { corn-soybean, original methods development, } \\
\text { Endoaquert silty clay }\end{array}$ & 0.94 & 295 & 6.8 & $0.40-0.64$ & 0.51 \\
\hline \multirow[t]{3}{*}{ D04 } & & & continuous corn, no $\mathrm{N}$ fertilizer, Year 1 & 0.61 & 89 & 3.2 & $0.12-0.19$ & 0.06 \\
\hline & 44 & $2-4-3$ & corn-oat-meadow-meadow, no $\mathrm{N}$ fertilizer, Year 2 & 0.86 & 272 & 7.4 & $0.39-0.63$ & 0.43 \\
\hline & & & corn-oat-meadow-meadow, $202 \mathrm{~kg} \mathrm{~N}^{-1}$, Year 2 & 0.40 & 197 & 8.7 & $0.22-0.35$ & 0.22 \\
\hline \multirow{3}{*}{$\begin{array}{l}\text { D05 } \\
\text { D06 }\end{array}$} & 4 & $2-4-1$ & corn-soybean, no-till & 0.81 & 100 & 3.5 & $0.18-0.28$ & 0.19 \\
\hline & & & native vegetation & 0.16 & 205 & 16.3 & $0.16-0.26$ & 0.18 \\
\hline & 5 & $2-5-1$ & corn-common bean, moldboard plow & 0.07 & 38 & 5.1 & $0.02-0.04$ & 0.03 \\
\hline \multirow[t]{4}{*}{ D07 } & & & continuous cotton, conventional tillage, irrigated & 0.04 & 111 & 42 & $0.11-0.17$ & 0.17 \\
\hline & & & wheat-cotton, reduced tillage & 0.15 & 97 & 13 & $0.12-0.19$ & 0.13 \\
\hline & 17 & $3-2-2$ & cotton with wheat cover crop, no-till & 0.03 & 46 & 34 & $0.06-0.10$ & 0.05 \\
\hline & & & cotton with wheat cover crop, no-till, irrigated & 0.04 & 12 & 4.1 & $0.01-0.02$ & 0.03 \\
\hline D07 & 17 & $3-2-2$ & sorghum-cotton, reduced tillage & 0.24 & 117 & 12.2 & $0.18-0.29$ & 0.18 \\
\hline D08 & 5 & $3-2-2$ & additions of barley straw & 0.09 & 345 & 63 & $0.34-0.55$ & 0.96 \\
\hline \multirow[t]{3}{*}{ D09 } & & & cotton-cotton-peanut, deep tilled, irrigated & 0.03 & 12.5 & 8.0 & $0.02-0.03$ & 0.03 \\
\hline & 12 & $3-1-2$ & peanut-cotton-cotton, deep tilled, irrigated & 0.03 & 18.5 & 13 & $0.03-0.04$ & 0.03 \\
\hline & & & continuous peanut, deep tilled, irrigated & 0.04 & 42 & 25 & $0.06-0.09$ & 0.06 \\
\hline \multirow[t]{2}{*}{ D10 } & & & native vegetation & 1.00 & 24 & 0.8 & $0.05-0.08$ & 0.06 \\
\hline & 2 & $4-4-1$ & native vegetation & 0.99 & 43 & 2.3 & $0.14-0.22$ & 0.14 \\
\hline \multirow[t]{3}{*}{ D11 } & & & vegetables with legume cover crop & 0.22 & 81 & 4.9 & $0.07-0.11$ & 0.06 \\
\hline & 4 & $2-3-3$ & vegetables with cereal cover crop & 0.16 & 80 & 5.8 & $0.06-0.09$ & 0.06 \\
\hline & & & vegetables, winter fallow & 0.20 & 53 & 3.4 & $0.04-0.07$ & 0.04 \\
\hline \multirow[t]{2}{*}{ D12 } & 5 & $2-3-$ & winter wheat, summer fallow, $90 \mathrm{~kg} \mathrm{~N}$ ha $^{-1}$ & 0.09 & 46 & 0.03 & $0.02-0.04$ & 0.03 \\
\hline & 5 & $2-3-$ & long-term pasture & 0.17 & 202 & 13.3 & $0.14-0.23$ & 0.18 \\
\hline V01 & 4 & $4-3-3$ & vetch, oat-wheat, reduced tillage & 0.69 & 380 & 30.6 & $>1$ & 1.00 \\
\hline \multirow[t]{3}{*}{ V02 } & & & medium-intensity cropping & 0.05 & 88 & 15.5 & $0.05-0.08$ & 0.06 \\
\hline & 8 & $2-4-4$ & long-term pasture & 0.10 & 156 & 15.5 & $0.10-0.16$ & 0.12 \\
\hline & & & native grass & 0.06 & 90 & 13.3 & $0.05-0.08$ & 0.06 \\
\hline \multirow[t]{2}{*}{ V03 } & 3 & $2-4-3$ & native pasture & 0.56 & 295 & 10.9 & $0.39-0.62$ & 0.51 \\
\hline & 3 & $2-4-3$ & conventional tillage, maize & 0.09 & 121 & 12.0 & $0.06-0.10$ & 0.09 \\
\hline \multirow[t]{3}{*}{ V04 } & & & continuous cotton, dryland, conventional tillage & 0.05 & 22 & 7.8 & $0.03-0.04$ & 0.04 \\
\hline & 4 & $3-1-2$ & cotton-wheat, dryland, conservation tillage & 0.05 & 46 & 16.5 & $0.05-0.09$ & 0.07 \\
\hline & & & Conservation Reserve Program (CRP) land & 0.08 & 49 & 12.2 & $0.06-0.10$ & 0.08 \\
\hline
\end{tabular}

appropriately. The SOC contents of the data sets ranged from 1.4 to $54.5 \mathrm{~g} \mathrm{~kg}^{-1}$, while BG activity ranged from 11 to $345 \mathrm{mg}$ PNP released $\mathrm{kg}^{-1} \mathrm{~h}^{-1}$. An additional 14 data sets from eight publications were used for an initial validation. The SOC contents for the validation data sets ranged from 3.1 to $38.0 \mathrm{~g} \mathrm{~kg}^{-1}$, while BG activity ranged from 21 to $380 \mathrm{mg}$ PNP released $\mathrm{kg}^{-1} \mathrm{~h}^{-1}$, with $\mathrm{BG}_{\mathrm{n}}$ values from 0.7 to $30.6 \mathrm{~g}$ PNP released kg ${ }^{-1} \mathrm{SOC}^{-1}$ incubation. For studies with multiple sampling depths, only surface samples were considered, and while most sampling depths were 0 to $5 \mathrm{~cm}$ ( $45 \%$ of the samples), some depths ranged to $20 \mathrm{~cm}$.

The general equation for the curves was based on a more-isbetter model and used the sigmoidal logistic model format:

$\beta$-glucosidase score $=$

$$
\frac{a}{1+b \exp \left(\frac{-c \beta \text {-glucosidase activity }}{1000}\right)}
$$

where the $a$ is a constant equal to $1.01 ; b$ is a constant set to 48.4 ; and $c$ is a factor that is equal to

$$
c=c_{1} c_{2}+c_{1} c_{2} c_{3}
$$

where $c_{1}$ is the SOM class factor, $c_{2}$ is the texture class factor, and $c_{3}$ is the climate class factor (Tables 1-3).

A stepwise procedure was used to develop the site-specific $c$ coefficient values, introducing only one new factor class at a time (listed in order in Tables 4 and 5). It was an iterative process, and not all points fit the model perfectly. We started with the data for semiarid sandy soils from western Texas (Acosta-Martínez et al., 2003b), and since that was a study that compared two sites that represented two SOM classes (Table 4), it was split. The data set first considered was the Paleustoll loam (Data Set D01) that fell within the following three factor classes: SOM class 2, texture class 2, and climate class 2, with three representative points listed in Table 5. For those data 
Table 5. (cont.)

\begin{tabular}{|c|c|c|c|c|c|c|c|c|}
\hline $\begin{array}{c}\text { Data set } \\
\text { ID+ }\end{array}$ & $\begin{array}{l}\text { Points in } \\
\text { data set } ¥\end{array}$ & Class§ & Management $\mathscr{\Upsilon}$ & $\begin{array}{c}\text { SOC } \\
\text { score \# }\end{array}$ & BG activity+† & $B G_{n} \neq \neq$ & $\begin{array}{c}\text { Target } \\
\text { range§§ }\end{array}$ & $\begin{array}{l}\text { Final BG } \\
\text { score } \llbracket \text { व }\end{array}$ \\
\hline & & & & & $\mathrm{mg} \mathrm{kg} \mathrm{g}^{-1} \mathrm{~h}^{-1}$ & $\mathrm{~kg}^{-1} \mathrm{~h}^{-1}$ & & \\
\hline \multirow[t]{4}{*}{ V05 } & \multirow{4}{*}{5} & \multirow{4}{*}{$3-2-2$} & cotton-cotton, dryland, conventional tillage & 0.05 & 28 & 8.9 & $0.03-0.04$ & 0.04 \\
\hline & & & wheat-cotton, dryland, conservation tillage & 0.09 & 78 & 13.5 & $0.08-0.13$ & 0.09 \\
\hline & & & CRP land & 0.33 & 121 & 10.7 & $0.22-036$ & 0.20 \\
\hline & & & native rangeland & 0.52 & 124 & 8.8 & $0.29-0.46$ & 0.20 \\
\hline \multirow[t]{5}{*}{ V06 } & & & CRP land & 0.16 & 144 & 12.8 & $0.13-0.21$ & 0.16 \\
\hline & & & native rangeland & 0.47 & 198 & 10.6 & $0.31-0.50$ & 0.31 \\
\hline & 11 & $2-2-2$ & wheat-cotton, dryland, conservation tillage & 0.11 & 192 & 21.5 & $0.15-0.24$ & 0.29 \\
\hline & & & sunflower, irrigated, conservation tillage & 0.11 & 96 & 10.6 & $0.07-0.12$ & 0.08 \\
\hline & & & native rangeland & 0.16 & 191 & 17.2 & $0.17-0.28$ & 0.29 \\
\hline \multirow[t]{2}{*}{ V07 } & \multirow{2}{*}{2} & \multirow{2}{*}{$2-3-4$} & managed (winter wheat) & 0.08 & 135 & 14.4 & $0.07-0.11$ & 0.09 \\
\hline & & & unmanaged (cemetery) & 0.14 & 190 & 13.7 & $0.12-0.20$ & 0.16 \\
\hline \multirow[t]{2}{*}{ V08 } & \multirow{2}{*}{2} & \multirow{2}{*}{$3-3-3$} & managed (annual rye grass) & 0.70 & 80 & 3.8 & $0.17-0.27$ & 0.08 \\
\hline & & & unmanaged (native grassland) & 0.79 & 111 & 4.8 & $0.24-0.38$ & 0.13 \\
\hline \multirow[t]{2}{*}{ V09 } & \multirow{2}{*}{2} & \multirow{2}{*}{$2-4-3$} & managed (Christmas tree) & 0.88 & 80 & 2.1 & $0.12-0.18$ & 0.06 \\
\hline & & & unmanaged (Douglas-fir forest) & 0.71 & 134 & 4.3 & $0.19-0.31$ & 0.11 \\
\hline V10 & 4 & $3-4-3$ & corn-soybean-winter wheat, no-till & 0.60 & 139 & 7.0 & $0.26-0.42$ & 0.19 \\
\hline V11 & 2 & $2-2-3$ & corn-soybean, no-till & 0.96 & 209 & 5.5 & $0.33-0.52$ & 0.29 \\
\hline \multirow[t]{4}{*}{ V12 } & \multirow{4}{*}{8} & \multirow{4}{*}{$3-2-3$} & corn-soybean-winter wheat, conventional tillage & 1.00 & 181 & 4.9 & $0.30-0.49$ & 0.38 \\
\hline & & & corn-soybean-winter wheat, no-till & 0.99 & 209 & 6.1 & $0.38-0.61$ & 0.51 \\
\hline & & & corn-soybean-winter wheat, no-till & 0.96 & 139 & 5.0 & $0.30-0.48$ & 0.22 \\
\hline & & & corn-soybean-winter wheat, conventional tillage & 0.61 & 103 & 6.1 & $0.23-0.27$ & 0.12 \\
\hline V13 & 4 & $2-4-3$ & native grassland, burned, fertilized & 0.67 & 21 & 0.7 & $0.03-0.05$ & 0.03 \\
\hline \multirow[t]{4}{*}{ V14 } & \multirow{4}{*}{12} & \multirow{4}{*}{$3-3-1$} & corn, no-till, no fertilizer, no cover crop & 0.25 & 58 & 5.7 & $0.09-0.14$ & 0.12 \\
\hline & & & corn, no-till, $16 \mathrm{~kg} \mathrm{~N}$ ha $^{-1}$, no cover crop & 0.48 & 92 & 6.6 & $0.20-0.31$ & 0.30 \\
\hline & & & corn, no-till, no fertilizer, no cover crop & 0.24 & 61 & 6.1 & $0.09-0.15$ & 0.13 \\
\hline & & & corn, no-till, no fertilizer, vetch cover crop & 0.53 & 172 & 11.7 & $0.39-0.62$ & 0.86 \\
\hline
\end{tabular}

$+\mathrm{D}$, development data set; $\mathrm{V}$, validation data set (see Table 4 for full identification).

₹ Number of points falling within the defined class.

$\S$ Soil organic matter class (Table 1)-texture class (Table 2)-climate class (Table 3).

I Crop in bold is the crop planted when samples were taken, otherwise samples were taken while the first crop listed was planted.

\# Soil organic C (SOC) indicator score calculated by the Soil Management Assessment Framework (Potter et al., 2006).

t+ BG, $\beta$-glucosidase activity in $\mathrm{mg} p$-nitrophenol (PNP) released $\mathrm{kg}^{-1}$ soil $\mathrm{h}^{-1}$ incubation.

$\neq \neq B G_{n}$, ratio of BG activity to SOC content, with final units of $g$ PNP released $\mathrm{kg}^{-1} \mathrm{SOC} \mathrm{h}^{-1}$ incubation.

$\S \S$ The target range for the $\mathrm{BG}$ index was calculated as $\left[\left(\mathrm{BG}_{\mathrm{n}} \times \mathrm{SOC}\right.\right.$ index $) /$ either 10 or 16] with the range of $10-16 \mathrm{~g}^{\mathrm{PNP}}$ released $\mathrm{kg}^{-1} \mathrm{SOC}^{-1}$ representing the $B_{n}$ values where $B G$ activity and $S O C$ appear to be in equilibrium (Fig. 2).

I 9 Using the endpoints and target range to set c-factor values (final values listed in Table 6), these are the final scores (using Eq. [1] and [2]) for the endpoints after several iterations.

points that had $\mathrm{BG}_{\mathrm{n}}$ values that fell within the stable range, the $\mathrm{BG}$ indicator value for each point was assumed to be about equal to the SOC indicator value for that point. For those $\mathrm{BG}_{\mathrm{n}}$ values falling below the stable range, e.g., those sample points where $B G$ activity was lower per unit $\mathrm{C}$ than found in "stable" areas, the BG indicator values were expected to be lower than the SOC indictor values, and a target range of values was calculated based on the interpolation of the degree of difference between the actual $B G_{n}$ and the stable $B G_{n}$ range $\left(10-17 \mathrm{~g} \mathrm{~kg}^{-1} \mathrm{~h}^{-1}\right)$ and the SOC content (Table 5). Each sequential data set was selected based on introducing one new factor class at a time. There were no data sets representing SOM class 1 (Tables 1 and 4), so a value was assigned based on an interpolation from the other values in that class.

It was rare to find a data set that had $\mathrm{BG}_{\mathrm{n}}$ values greater than the stable range. One example was D08 (Martens et al., 1992), where large amount of manures or plant residues had been added to the soil. The $\mathrm{BG}_{\mathrm{n}}$ values at the end of the 31-mo study period ranged from 28 to 63 , therefore the highest BG activity was set as the near-maximum level of activity for that soil and climate type.

Another anomalous data set was D10, a study of native Cerrado soils, where the BG activity was highly correlated with soil P rather than SOC (Green and Stott, unpublished data, 2008). The BG activities were quite low, despite high SOC indicator values (Table 5), with $\mathrm{BG}_{\mathrm{n}}$ values ranging from 0.8 to $2.3 \mathrm{~g}$ PNP released $\mathrm{kg}^{-1} \mathrm{SOC} \mathrm{h}^{-1}$ incubation (Table 4).

Once the $c$-factor values were set (Table 6), a family of related indicator equations and curves were generated (Fig. 2). The final results of calculating BG indicator values for the development data sets are summarized in Table 7 . The correlations $(r)$ between the SOC and BG activity indicator values were similar in most cases $( \pm 0.1)$ to the correlations between the SOC contents and BG activities in a given study. The one exception was D04. This study (Dodor and Tabatabai, 2005) measured changes due to rotation phase (corn, soybean, oat [Avena sativa L.], or alfalfa [Medicago sativa L.] meadow in various combinations), in 
Table 6. Site-specific coefficient (c-factor) values for the $\beta$-glucosidase activity indicator as modified by the soil organic matter class, based on soil orders and suborders (Table 1), the texture class (Table 2), and the climate class (Table 3). Values were determined using the data sets listed in Table 4 .

\begin{tabular}{lc} 
Class & $\boldsymbol{c}$ factor \\
\hline Soil organic matter, $c_{1}$ & \\
1 & 0.9 \\
2 & 2.9 \\
3 & 3.8 \\
4 & 5.8 \\
Texture, $c_{2}$ & \\
1 & 4.0 \\
2 & 2.9 \\
3 & 2.8 \\
4 & 2.7 \\
5 & 1.3 \\
Climate, $C_{3}$ & \\
1 & 2.10 \\
2 & 0.85 \\
3 & 0.70 \\
4 & 0.45 \\
\hline
\end{tabular}

which the meadow phase accrued C, but tillage in the corn phase resulted in the rapid loss of accrued C. Here a flush of $\mathrm{C}$ due to tilling and a spike in the microbial population occurred, with a lag before increases BG activity would be seen.

\section{Validation with Published Data}

Additional data sets meeting the same requirements as the development data sets were used for an initial validation of the proposed BG SMAF indicator. Some of the factor class combinations were the same as the development sets but from different studies, sites, and management systems, while others were unique combinations (Tables 4 and 5). Again, the correlations between

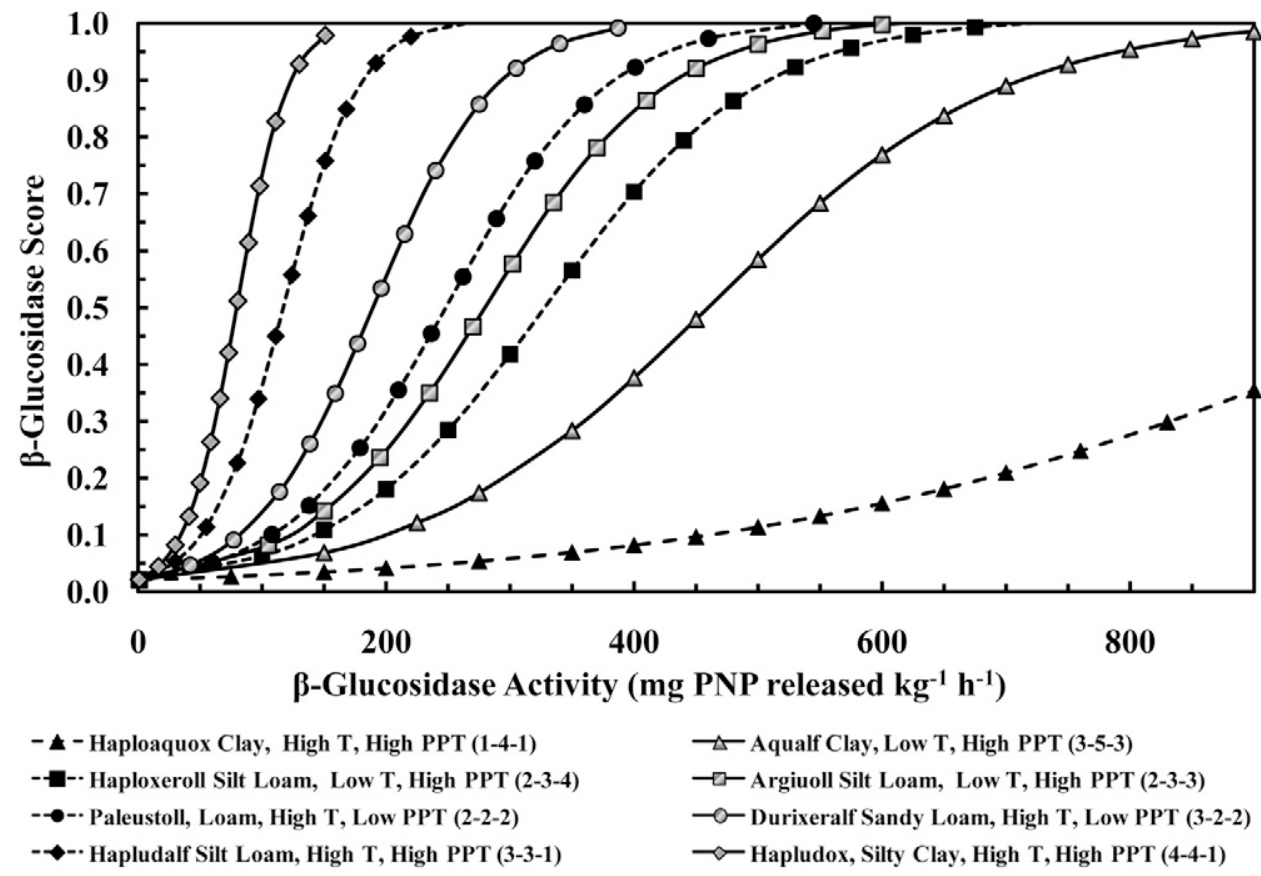

Fig. 2. Selection of curves based on Eq. [1] and [2] as well as the c-factor values listed in Table 6. The numbers in the legend represent the factor class designations in the following order: soil organic matter (based on soil taxonomy), texture, and climate (based on temperature [T] and precipitation [PPT]). the SOC and BG activity indicator values for most of the data sets were about the same as those between the SOC contents and BG activities within a given data set (Table 7 ). There was one exception, V06, which had a large discrepancy between the two $r$ values (observed vs. scored SOC and BG). This study (Acosta-Martínez et al., 2003a) compared conservation systems across four soil types, with one falling into the factor class combination 3-1-2 (V04), one into 3-2-2 (V05), and two into 2-2-2 (V06). The SOC indicator values were quite low; however, the $\mathrm{BG}$ activities were relatively high, with $\mathrm{BG}_{\mathrm{n}}$ values ranging from 8.2 to $21.5 \mathrm{~g}$ PNP released kg ${ }^{-1} \mathrm{SOC}^{-1}$ incubation and a number of data points exceeding the stable range. The treatments varied among long-term CRP land ( $12 \mathrm{yr}$ ), native rangeland, and cropland under current management for 5 or more years. Apparently for these latter sites, the BG activities were in flux and increasing faster than the SOC contents. For all data sets, the $\mathrm{BG}$ indicators retained the sensitivity to changes in management seen in the original data.

\section{Field Experiment}

As part of a larger study (Tanaka et al., 2007), SOC and BG activities were measured in 10 cropping systems under no-till management in a semiarid environment (Table 8). The sites had been in a sunflower-spring wheat-spring wheat rotation before implementation. Samples were collected the spring before the experiment was implemented at each site, following spring wheat, and again the following spring after the 10 crops were harvested. Management systems were implemented at the north site 1 yr earlier than the south site, but otherwise the two sites had identical treatments. The SOC contents varied from 26.7 to $30.2 \mathrm{~g} \mathrm{~kg}^{-1}$ at the north site and from 18.2 to 26.4 at the south site (Table 8). The

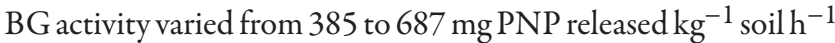
incubation at the north site, and 248 to $531 \mathrm{mg}$ PNP released kg ${ }^{-1}$ soil h$^{-1}$ incubation at the south site (Table 8). There was no crop that had consistently higher or lower BG activities than the other crops. The north site overall had significantly higher SOC contents and BG activities than the south site. At both sites, the overall mean SOC contents and BG activities trended downward from the first to the second year, although individual plots might trend in either direction, depending on the crop. When BG activities were normalized to SOC, all the BG were $10 \mathrm{~g}$ PNP released $\mathrm{kg}^{-1} \mathrm{SOC} \mathrm{h}^{-1}$, with many above 17 . There was no distinct pattern with regard to crop type, but since all sites were in notill, the surface layer may still be accruing C. For the north site, SOC contents explained $86 \%$ of the BG 
Table 7. Summary of the values used for the calculation of indicator scores using the Soil Management Assessment Framework (SMAF) for the soil organic C (SOC) content factor (Andrews et al., 2004) and Eq. [1] for the $\beta$-glucosidase activity (BG) factor.

\begin{tabular}{|c|c|c|c|c|c|c|c|c|}
\hline $\begin{array}{c}\text { Data set } \\
\text { IDt }\end{array}$ & $\begin{array}{l}\text { SOC vs. } \\
\text { BG }(r) \mp\end{array}$ & Class§ & $\begin{array}{c}\text { c factor for SOC } \\
\text { scores } \uparrow\end{array}$ & $\begin{array}{c}\text { Range of } \\
\text { SOC scores }\end{array}$ & $\begin{array}{l}\text { Range of } B G_{n} \\
\text { values } \#\end{array}$ & $\begin{array}{c}c \text { factor for BG } \\
\text { scorestt }\end{array}$ & $\begin{array}{c}\text { Range of BG } \\
\text { scores } ¥\end{array}$ & $\begin{array}{l}\text { SOC scores vs. } \\
\text { BG scores }(r)\end{array}$ \\
\hline D01 & 0.90 & $2-2-2$ & 2.034 & $0.11-0.19$ & $4.8-12.8$ & 15.56 & $0.04-0.19$ & 0.89 \\
\hline D02 & 0.40 & $2-2-3$ & 1.841 & $0.33-0.69$ & $4.1-13.6$ & 14.30 & $0.07-0.52$ & 0.31 \\
\hline D03 & 0.23 & $2-4-3$ & 1.546 & $0.50-0.99$ & $1.9-6.8$ & 13.31 & $0.07-0.51$ & 0.27 \\
\hline D04 & 0.37 & $2-4-3$ & 1.546 & $0.40-0.95$ & $3.2-8.7$ & 13.31 & $0.06-0.43$ & 0.98 \\
\hline D05 & -0.27 & $2-4-1$ & 1.872 & $0.77-0.98$ & $1.7-3.5$ & 24.27 & $0.07-0.19$ & -0.38 \\
\hline D06 & 0.91 & $2-5-1$ & 1.783 & $0.07-0.16$ & $5.1-16.3$ & 11.69 & $0.03-0.18$ & 0.90 \\
\hline D07 & 0.73 & $3-2-2$ & 2.848 & $0.03-0.24$ & $4.1-42.0$ & 20.39 & $0.02-0.18$ & 0.66 \\
\hline D08 & 0.03 & $3-2-2$ & 2.848 & $0.06-0.14$ & $27.7-63.0$ & 20.39 & $0.36-0.96$ & 0.02 \\
\hline D09 & 0.76 & $3-1-2$ & 3.646 & $0.03-0.04$ & $8.0-24.9$ & 28.12 & $0.03-0.06$ & 0.73 \\
\hline D10 & -0.13 & $4-4-1$ & 4.601 & 0.99-1.00 & $0.8-2.3$ & 48.55 & $0.06-0.14$ & -0.07 \\
\hline D11 & -0.31 & $2-3-3$ & 1.620 & $0.16-0.22$ & $3.4-5.8$ & 13.80 & $0.04-0.06$ & -0.27 \\
\hline D12 & 0.90 & $2-3-4$ & 1.535 & $0.07-0.17$ & $4.3-13.3$ & 11.77 & $0.03-0.18$ & 0.94 \\
\hline V01 & 0.95 & $4-3-3$ & 3.800 & $0.44-0.69$ & $21.0-30.6$ & 26.62 & $0.88-1.00$ & 0.93 \\
\hline V02 & 0.73 & $2-4-4$ & 1.744 & $0.05-0.10$ & $7.1-15.5$ & 12.19 & $0.03-0.12$ & 0.80 \\
\hline V03 & 0.95 & $2-4-3$ & 1.546 & $0.09-0.56$ & $10.9-14.8$ & 13.31 & $0.09-0.51$ & 0.95 \\
\hline V04 & 0.37 & $3-1-2$ & 3.646 & $0.05-0.08$ & $6.8-16.5$ & 28.12 & $0.04-0.08$ & 0.43 \\
\hline V05 & 0.95 & $3-2-2$ & 2.848 & $0.05-0.52$ & $6.4-13.5$ & 20.39 & $0.03-0.20$ & 0.94 \\
\hline V06 & 0.83 & $2-2-2$ & 2.034 & $0.04-0.47$ & $8.0-21.5$ & 15.56 & $0.03-0.43$ & 0.68 \\
\hline V07 & NA§§ & $2-3-4$ & 1.535 & $0.08-0.14$ & $13.7-14.4$ & 11.77 & $0.09-0.16$ & NA \\
\hline V08 & NA & $3-3-3$ & 2.268 & $0.70-0.79$ & $3.8-4.8$ & 18.09 & $0.08-0.13$ & NA \\
\hline V09 & NA & $2-4-3$ & 1.546 & $0.71-0.88$ & $2.1-4.3$ & 13.31 & $0.06-0.11$ & NA \\
\hline V10 & -0.36 & $3-4-3$ & 2.165 & $0.55-0.74$ & $5.5-7.0$ & 17.44 & $0.12-0.19$ & -0.33 \\
\hline V11 & NA & $2-3-3$ & 1.841 & $0.81-0.96$ & $5.5-5.8$ & 14.30 & $0.18-0.29$ & NA \\
\hline V12 & 0.58 & $3-2-3$ & 2.577 & $0.61-1.00$ & $2.6-6.1$ & 18.73 & $0.10-0.51$ & 0.49 \\
\hline V13 & 0.42 & $2-4-3$ & 1.546 & $0.67-0.82$ & $0.7-1.3$ & 13.31 & $0.03-0.04$ & 0.42 \\
\hline V14 & 0.84 & $3-3-1$ & 2.745 & $0.25-0.67$ & $5.7-11.7$ & 32.98 & $0.12-0.86$ & 0.83 \\
\hline
\end{tabular}

$\mathrm{t} \mathrm{D}$, development data set; $\mathrm{V}$, validation data set (see Table 4 for full identification).

₹ Coefficient of correlation of the observed values.

§ Soil organic matter class (Table 1)-texture class (Table 2)-climate class (Table 3).

- Calculated by SMAF (Andrews et al., 2004; Potter et al., 2006).

\# $\mathrm{BG}_{\mathrm{n}}$, BG normalized to the SOC content of the soil (BG/SOC), with final units of mg p-nitrophenol released $\mathrm{kg}^{-1} \mathrm{SOC} \mathrm{h}^{-1}$ incubation.

t+ Calculated using Eq. [2] and values in Table 6.

\#キ BG activity score as calculated by Eq. [1].

$\S \S N A$, not applicable (data not available to make the calculation).

activity variation, while $82 \%$ of the variation in the south site values was explained, and when the sites were combined, $66 \%$ of the variation was explained by the SOC values.

Using the site-specific BG activity indicator developed here, the experimental site fell into the following factor classes: SOM class $2\left(c_{1}=2.9\right)$, texture class $3\left(c_{2}=2.8\right)$, and climate class $4\left(c_{3}=0.45\right)$. The $\mathrm{BG}$ indicator scores ranged from 0.66 to 1.00 for the north site and 0.32 to 0.92 for the south site. When the 16 points from the stable group were added to the data found in the developmental and validation data sets in the same $B G_{n}$ range (Table 8 ), $94 \%$ of the variation in BG activity could be explained by the SOC contents in the stable group. In the highrange group, the addition of the experimental data improved the comparison significantly $\left(r^{2}=0.91\right)$.

\section{CONCLUSIONS}

Our evaluation of published data demonstrated the applicability of BG activity as a sensitive indicator of soil quality to be added to the SMAF. This will allow the SMAF to incorporate soil metabolic functioning in an overall assessment of soil quality. The BG activity has proven to be sensitive to a variety of dif- ferent management regimes in several different climatic regions with various soil types and textures. This enzyme is an important indicator of the ability of a given soil ecosystem to degrade plant material and provide simple sugars for the microbial population. Soil enzyme activities, including BG, are generally simple, lowcost measurements to perform, especially compared with other biochemical measures.

Using data sets from a variety of native and natural ecosystems, a family of BG scoring curves to be used with the SMAF was developed. These initial curves may be modified as more data become available, especially maximum values that might be seen in native habitats. The scoring curves appropriately rank soil and crop management practices with regard to the observed BG activity in the field. Further validation of this indicator measurement, as part of a suite of indicators, will be part of the CEAP soil quality and other research experiments that utilize the SMAF to assess management impacts on soil quality. Including BG activity in the SMAF increases the sensitivity of this assessment tool, especially because measuring BG has the potential to detect changes due to shifting soil management sooner than measurements of SOC or other soil properties. 
Table 8. Results from a field experiment conducted near Mandan, ND, and calculations of the Soil Management Assessment Framework scores for soil organic $\mathrm{C}(\mathrm{SOC})$ and $\beta$-glucosidase (BG) activity.

\begin{tabular}{|c|c|c|c|c|c|}
\hline Cropt & BG‡ & SOC§ & SOC score $₫$ & $\mathrm{BG}_{\mathrm{n}} \#$ & BG scoret- \\
\hline & $\mathrm{mg} \mathrm{kg}^{-1} \mathrm{~h}^{-1}$ & $\mathrm{~g} \mathrm{~kg}^{-1}$ & & $\mathrm{~g} \mathrm{~kg}^{-1} \mathrm{~h}^{-1}$ & \\
\hline \multicolumn{6}{|c|}{ North site, Year 1 (following spring wheat) } \\
\hline Buckwheat & 505 & 28.6 & 0.62 & 17.7 & 0.90 \\
\hline Canola & 600 & 29.0 & 0.63 & 20.7 & 0.97 \\
\hline Chickpea & 564 & 29.4 & 0.65 & 19.2 & 0.95 \\
\hline Corn & 599 & 29.1 & 0.64 & 20.5 & 0.97 \\
\hline Dry Pea & 601 & 30.2 & 0.67 & 19.9 & 0.97 \\
\hline Lentil & 576 & 26.4 & 0.53 & 21.8 & 0.96 \\
\hline Sorghum & 618 & 32.1 & 0.73 & 19.3 & 0.98 \\
\hline Sunflower & 687 & 29.0 & 0.63 & 23.7 & 1.00 \\
\hline Wheat & 663 & 29.1 & 0.63 & 22.8 & 0.99 \\
\hline \multicolumn{6}{|c|}{ North site, Year 2 (following crops listed below) } \\
\hline Buckwheat & 486 & 27.0 & 0.56 & 18.0 & 0.87 \\
\hline Canola & 426 & 28.9 & 0.63 & 14.7 & 0.76 \\
\hline Chickpea & 466 & 29.3 & 0.64 & 15.9 & 0.84 \\
\hline Corn & 420 & 30.1 & 0.67 & 13.9 & 0.75 \\
\hline Dry Pea & 385 & 30.0 & 0.67 & 12.8 & 0.66 \\
\hline Lentil & 416 & 26.7 & 0.55 & 15.6 & 0.74 \\
\hline Millet & 440 & 27.1 & 0.56 & 16.2 & 0.79 \\
\hline Sorghum & 479 & 29.2 & 0.64 & 16.4 & 0.86 \\
\hline Sunflower & 587 & 28.5 & 0.61 & 20.6 & 0.96 \\
\hline Wheat & 622 & 28.3 & 0.61 & 22.0 & 0.98 \\
\hline \multicolumn{6}{|c|}{ South site, Year 1 (following spring wheat) } \\
\hline Buckwheat & 279 & 21.8 & 0.36 & 12.8 & 0.36 \\
\hline Canola & 319 & 20.2 & 0.31 & 15.8 & 0.47 \\
\hline Chickpea & 439 & 25.4 & 0.50 & 17.3 & 0.79 \\
\hline Corn & 384 & 20.2 & 0.31 & 19.1 & 0.66 \\
\hline Dry Pea & 466 & 25.0 & 0.48 & 18.7 & 0.84 \\
\hline Lentil & 438 & 23.1 & 0.41 & 19.0 & 0.79 \\
\hline Millet & 339 & 22.5 & 0.39 & 15.1 & 0.53 \\
\hline Sorghum & 338 & 19.0 & 0.27 & 17.8 & 0.53 \\
\hline Sunflower & 376 & 23.0 & 0.41 & 16.3 & 0.64 \\
\hline Spring Wheat & 531 & 26.4 & 0.53 & 20.1 & 0.92 \\
\hline \multicolumn{6}{|c|}{ South site, Year 2 (following crops listed below) } \\
\hline Buckwheat & 358 & 18.6 & 0.26 & 19.3 & 0.59 \\
\hline Canola & 371 & 19.8 & 0.30 & 18.7 & 0.63 \\
\hline Chickpea & 391 & 21.0 & 0.33 & 18.6 & 0.68 \\
\hline Corn & 248 & 18.2 & 0.25 & 13.6 & 0.28 \\
\hline Dry Pea & 395 & 21.7 & 0.36 & 18.2 & 0.69 \\
\hline Lentil & 345 & 20.0 & 0.30 & 17.3 & 0.55 \\
\hline Millet & 302 & 19.8 & 0.29 & 15.3 & 0.43 \\
\hline Sorghum & 290 & 18.3 & 0.25 & 15.9 & 0.39 \\
\hline Sunflower & 265 & 19.7 & 0.29 & 13.5 & 0.32 \\
\hline Spring Wheat & 265 & 21.2 & 0.34 & 12.5 & 0.32 \\
\hline
\end{tabular}

† Samples were collected in the spring before planting operations before (Year 1) and after (Year 2) the listed crops. At both sites, Year 1 reflected a baseline sampling that followed a 3-yr sunflower-spring wheat-spring wheat rotation. Sampling in Year 2 occurred the spring following the harvest of the 10 listed crops.

₹ $\beta$-glucosidase activity reported as $\mathrm{mg}$ p-nitrophenol released $\mathrm{kg}^{-1}$ soil $^{-1}$ incubation.

$\S$ SOC content as g SOC $\mathrm{kg}^{-1}$ soil.

- Calculated using the Soil Management Assessment Framework (Andrews et al., 2004).

\# BG normalized to the SOC content of the soil (BG/SOC), with final units of $\mathrm{mg}$ p-nitrophenol released $\mathrm{kg}^{-1} \mathrm{SOC}^{-1}$ incubation.

+十 BG activity score as calculated by Eq. [1], using the values in Table 6 to calculate the $\mathrm{c}$ factor. For this site, $\mathrm{c}_{1}=2.9, \mathrm{c}_{2}=2.8, \mathrm{c}_{3}=2.45$, and using Eq. [2], c $=11.78$.
To fully test the concept that the $B G_{n}$ ratio is a predictor of trends in $\mathrm{C}$ sequestration, studies that measure changes in enzyme activities for several years are needed. To test this indicator model, sites with high, near-maximum BG activities need to be sampled. Such sites would be native ecosystems or long-term pastures that have high SOC contents relative to the factor classes (Tables 1-3) representing the site.

The SMAF is a malleable model, as is the BG indicator developed here. It is hoped that others will use and modify the indicator and SMAF tool as necessary when new data become available. In the meantime, this indicator will allow soil enzymatic activity involved in $\mathrm{C}$ cycling to be assessed when using the SMAF ecosystem function analysis.

\section{REFERENCES}

Acosta-Martínez, V., L. Cruz, D. Sotomayor-Ramirez, and L. Perez-Alegria. 2007a. Enzyme activities as affected by soil properties and land use in a tropical watershed. Appl. Soil Ecol. 35:35-45.

Acosta-Martínez, V., S. Klose, and T.M. Zobeck. 2003a. Enzyme activities in semiarid soils under Conservation Reserve Program, native rangeland, and cropland. J. Plant Nutr. Soil Sci. 166:699-707.

Acosta-Martínez, V., M.M. Mikha, and M.F. Vigil. 2007b. Microbial communities and enzyme activities in soils under alternative crop rotations compared to wheat-fallow for the central Great Plains. Appl. Soil Ecol. $37: 41-52$.

Acosta-Martínez, V., D.R. Upchurch, A.M. Schubert, D. Porter, and T. Wheeler. 2004. Early impacts of cotton and peanut cropping systems on selected soil chemical, physical, microbiological and biochemical properties. Biol. Fertil. Soils 40:44-54.

Acosta-Martínez, V., T.M. Zobeck, T.E. Gill, and A.C. Kennedy. 2003b. Enzyme activities and microbial community structure in semiarid agricultural soils. Biol. Fertil. Soils 38:216-227.

Ajwa, H.A., C.J. Dell, and C.W. Rice. 1999. Changes in enzyme activities and microbial biomass of tallgrass prairie soil as related to burning and nitrogen fertilization. Soil Biol. Biochem. 31:769-777.

Andrews, S.S., D.L. Karlen, and C.A. Cambardella. 2004. The soil management assessment framework: A quantitative soil quality evaluation method. Soil Sci. Soc. Am. J. 68:1945-1962.

Aon, M.A., and A.C. Colaneri. 2001. II. Temporal and spatial evolution of enzymatic activities and physico-chemical properties in an agricultural soil. Appl. Soil Ecol. 18:255-270.

Bandick, A.K., and R.P. Dick. 1999. Field management effects on soil enzyme activities. Soil Biol. Biochem. 31:1471-1479.

Bastida, F., J.L. Moreno, T. Hernandez, and C. Garcia. 2006. Microbiological degradation index of soils in a semiarid climate. Soil Biol. Biochem. 38:3463-3473.

Bergstrom, D.W., C.M. Monreal, and D.J. King. 1998. Sensitivity of soil enzyme activities to conservation practices. Soil Sci. Soc. Am. J. 62:1286-1295.

Cambardella, C.A., T.B. Moorman, S.S. Andrews, and D.L. Karlen. 2004. Watershed-scale assessment of soil quality in the loess hills of southwest Iowa. Soil Tillage Res. 78:237-247.

de la Horra, A.M., M.E. Conti, and R.M. Palma. 2003. $\beta$-Glucosidase and proteases activities as affected by long-term management practices in a Typic Argiudoll soil. Commun. Soil Sci. Plant Anal. 34:2395-2404.

Deng, S.P., and M.A. Tabatabai. 1996. Effect of tillage and residue management on enzyme activities in soils: 2. Glycosidases. Biol. Fertil. Soils 22:208-213.

Dick, R.P., D.P. Breakwell, and R.F. Turco. 1996. Soil enzyme activities and biodiversity measurements as integrative microbiological indicators. p. 247-271. In J.W. Doran and A.J. Jones (ed.) Methods for assessing soil quality. SSSA Spec. Publ. 49. SSSA, Madison, WI.

Dodor, D.E., and M.A. Tabatabai. 2005. Glycosidases in soils as affected by cropping systems. J. Plant Nutr. Soil Sci. 168:749-758.

Doran, J.W. 2002. Soil health and global sustainability: Translating science into practice. Agric. Ecosyst. Environ. 88:119-127.

Dumontet, S., A. Mazzatura, C. Casucci, and P. Perucci. 2001. Effectiveness of microbial indexes in discriminating interactive effects of tillage and crop 
rotations in a Vertic Ustorthents. Biol. Fertil. Soils 34:411-416.

Eivazi, F., and M.A. Tabatabai. 1988. Glucosidases and galactosidases in soils. Soil Biol. Biochem. 20:601-606.

Elliott, E.T., and D.C. Coleman. 1988. Let the soil work for us. Ecol. Bull. 39:23-32.

Green, V.S., D.E. Stott, J.C. Cruz, and N. Curi. 2007. Tillage impacts on soil biological activity and aggregation in a Brazilian Cerrado Oxisol. Soil Tillage Res. 92:114-121.

Hendrix, P.F., D.A. Crossley, Jr., J.M. Blair, and D.C. Coleman. 1990. Soil biota as components of sustainable agroecosystems. p. 637-654. In C.A. Edwards et al. (ed.) Sustainable agricultural systems. Soil Water Conserv. Soc., Ankeny, IA.

Idowu, O.J., H.M. van Es, G.S. Abawi, D.W. Wolfe, J.I. Ball, B.K. Gugino, B.N. Moebius, R.R. Schindelbeck, and A.V. Bilgili. 2008. Farmer-oriented assessment of soil quality using field, laboratory, and VNIR spectroscopy methods. Plant Soil 307:243-253.

Karlen, D.L., S.S. Andrews, and J.W. Doran. 2001. Soil quality: Current concepts and applications. Adv. Agron. 74:1-40.

Karlen, D.L., and D.E. Stott. 1994. A framework for evaluating physical and chemical indicators of soil quality. p. 53-72. In J.W. Doran (ed.) Defining soil quality for a sustainable environment. SSSA Spec. Publ. 35. SSSA and ASA, Madison, WI.

Karlen, D.L., M.D. Tomer, J. Neppel, and C.A. Cambardella. 2008. A preliminary watershed scale soil quality assessment in north central Iowa, USA. Soil Tillage Res. 99:291-299.

Kennedy, A.C., and R.I. Papendick. 1995. Microbial characteristics of soil quality. J. Soil Water Conserv. 50:243-252.

Knight, T.R., and R.P. Dick. 2004. Differentiating microbial and stabilized betaglucosidase activity relative to soil quality. Soil Biol. Biochem. 36:2089-2096.

Leon, M.C.C., A. Stone, and R.P. Dick. 2006. Organic soil amendments: Impacts on snap bean common root rot (Aphanomyes euteiches) and soil quality. Appl. Soil Ecol. 31:199-210.

Liebig, M.A., M.E. Miller, G.E. Varvel, J.W. Doran, and J.D. Hanson. 2004 AEPAT: Software for assessing agronomic and environmental performance of management practices in long-term agroecosystem experiments. Agron. J. 96:109-115.

Lightle, D. 2007. Revised Universal Soil Loss Equation, Version 2 (RUSLE2); official NRCS program; official NRCS database. Available at fargo.nserl. purdue.edu/rusle2_dataweb/RUSLE2_Index.htm (verfied 18 Sept. 2009). Natl. Soil Erosion Res. Lab., West Lafayette, IN.

Martens, D.A., J.B. Johanson, and W.T. Frankenberger, Jr. 1992. Production and persistence of soil enzymes with repeated addition of organic residues. Soil Sci. 153:53-61.

Miller, M., and R.P. Dick. 1995. Thermal stability and activities of soil enzymes as influenced by crop rotations. Soil Biol. Biochem. 27:1161-1166.

Moore, J.M., S. Klose, and M.A. Tabatabai. 2000. Soil microbial biomass carbon and nitrogen as 15 affected by cropping systems. Biol. Fertil. Soils 31:200-210.

Mullen, M.D., C.G. Melhorn, D.D. Tyler, and B.N. Duck. 1998. Biological and biochemical soil properties in no-till corn with different cover crops. J. Soil Water Conserv. 53:219-224.

National Research Council. 1993. Soil and water quality: An agenda for agriculture. Natl. Acad. Press, Washington, DC.

Ndiaye, E.L., J.M. Sandeno, D. McGrath, and R.P. Dick. 2000. Integrative biological indicators for detecting change in soil quality. Am. J. Alternative Agric. 15:26-36.

NRCS. 2002. Soil management. Subpart 508C. In National agronomy manual. 190-V-NAM. 3rd ed. U.S. Gov. Print. Office, Washington, DC.

NRCS. 2006. Land resource regions and Major Land Resource Areas of the United States, the Caribbean, and the Pacific Basin. Agric. Handbk. 296. U.S. Gov. Print. Office, Washington, DC.

Pierce, F.J., M.J. Shaffer, and A.D. Halvorson. 1991. Screening procedure for estimating potentially leachable nitrate-nitrogen below the root zone. p. 259-283. In R.F. Follett et al. (ed.) Managing nitrogen for groundwater quality and farm profitability. SSSA, Madison, WI.

Potter, S.R., S. Andrews, J.D. Atwood, R.L. Kellogg, J. Lemunyon, L. Norfleet, and D. Oman. 2006. Model simulation of soil loss, nutrient loss, and change in soil organic carbon associated with crop production. Available at www. nrcs.usda.gov/technical/nri/ceap/croplandreport/ (verified 30 Sept. 2009). Conservation Effects Assessment Project, NRCS, Washington, DC.

Quisenberry, V.L., B.R. Smith, R.E. Phillips, H.D. Scott, and S. Nortcliff. 1993. A soil classification system for describing water and chemical transport. Soil Sci. 156:306-315.

Richardson, C.W., D.A. Bucks, and E.J. Sadler. 2008. The Conservation Effects Assessment Project benchmark watersheds: Synthesis of preliminary findings. J. Soil Water Conserv. 63:590-604.

Roldán, A., J.R. Salinas-García, M.M. Alguacil, E. Díaz, and F. Caravaca. 2005. Soil enzyme activities suggest advantages of conservation tillage practices in sorghum cultivation under subtropical conditions. Geoderma 129:178-185.

Sparling, G.P. 1997. Soil microbial biomass, activity and nutrient cycling as indicators of soil health. p. 97-119. In C. Pankhurst et al. (ed.) Biological indicators of soil health. CAB Int., New York.

Tabatabai, M.A. 1994. Soil enzymes. p. 835-864. In R.W. Weaver et al. (ed.) Methods of soil analysis. Part 2. Microbiological and biochemical properties. SSSA Book Ser. 5. SSSA, Madison, WI.

Tanaka, D.L., J.M. Krupinsky, S.D. Merrill, M.A. Liebig, and J.D. Hanson. 2007. Dynamic cropping systems for sustainable crop production in the Northern Great Plains. Agron. J. 99:904-911.

Taylor, J.P., B. Wilson, M.S. Mills, and R.G. Burns. 2002. Comparison of microbial numbers and enzymatic activities in surface soils and subsoils using various techniques. Soil Biol. Biochem. 34:387-401.

Turner, B.L., D.W. Hopkins, P.M. Haygarth, and N. Ostle. 2002. $\beta$-Glucosidase activity in pasture soils. Appl. Soil Ecol. 20:157-162.

USDA-ARS. 2005. Overview of RUSLE2. Available at www.ars.usda.gov/ research/docs.htm?docid $=6010 \& p f=1 \& c g \_i d=0$ (verified 18 Sept. 2009). Watershed Phys. Processes Res. Unit, Oxford, MS.

Wienhold, B.J., D.L. Karlen, S.S. Andrews, and D.E. Stott. 2009. Protocol for indicator scoring in the Soil Management Assessment Framework (SMAF) Renew. Agric. Food Syst. (in press), doi:10.1017/S1742170509990093.

Wienhold, B.J., J.L. Pikul, M.A. Liebig, M.M. Mikha, G.E. Varvel, J.W. Doran, and S.S. Andrews. 2006. Cropping system effects on soil quality in the Great Plains: Synthesis from a regional project. Renew. Agric. Food Syst. 21:49-59.

Zobeck, T.M., A.D. Halvorson, B. Wienhold, V. Acosta-Martínez, and D.L. Karlen. 2008. Comparison of two soil quality indexes to evaluate cropping systems in northern Colorado. J. Soil Water Conserv. 63:329-338. 